\title{
Antifungal and antioxidant activity of stem bark extracts of Ficus religiosa $\mathrm{L}$.
}

\author{
Aqsa Shahid, Zeb Saddiqe* and Khajista Jabeen \\ Department of Botany, Lahore College for Women University, Lahore-Pakistan \\ *Corresponding author's email: zeb_rukhsana@yahoo.com
}

Citation

Aqsa Shahid, Zeb Saddiqe and Khajista Jabeen. Antifungal and antioxidant activity of stem bark extracts of Ficus religiosa L. Pure and Applied Biology. Vol. 5, Issue 4, pp1304-1315. http://dx.doi.org/10.19045/bspab.2016.50157

\begin{tabular}{llll}
\hline \hline Received: 23/07/2016 & Revised: 30/11/2016 & Accepted: 04/12/2016 & Online First: 09/12/2016 \\
\hline
\end{tabular}

\section{Abstract}

Aspergillus niger is a major cause of black moulds, stem and root rots of several plant species. These diseases are mainly controlled by using agrichemicals. However, these chemicals have adverse effects on environment. To avoid the use of synthetic toxic chemicals, researchers are focusing on plant derived natural products which can inhibit the growth of these pathogens. The present study is based on evaluating different solvent fractions of stem bark of Ficus religiosa L. for antifungal activity against $A$. niger at $0.25,0.5,1$ and $2 \mathrm{mg} / \mathrm{mL}$ concentrations using agar dilution method. Antioxidant potential of the extracts was also determined by DPPH radical scavenging assay. The plant showed significant antifungal activity with highest activity observed for the $n$-butanol fraction showing 66 to $77.5 \%$ inhibition of fungal growth at the tested concentrations. Least active was the ethyl acetate fraction with \% inhibition ranging from $47.5 \%$ to $62.5 \%$ at the tested concentrations. The extracts also showed significant antioxidant activity with highest activity of $91.71 \%$ observed for dichloromethane fraction. Phytochemical analysis indicated the presence of glycosides, alkaloids, saponins, tannins, flavonoids, triterpenes, sterols and phenols in the extracts. The study concluded that the stem bark of F. religiosa can be a good source of antifungal compounds with antioxidant activity.

Keywords: Ficus religiosa; Aspergillus niger; Antifungal activity; Antioxidant activity; DPPH

\section{Introduction}

Fungi are found all over the world, attacking plants and causing diseases [1]. Fungi have been the cause of many famine and economic losses due to the diseases they cause and are reported in the history of many countries $[2,3]$. The number of fatalities due to fungal diseases is often vast, because in addition to its effect on field and yield, losses to storage products are also considered [4]. Beside this, it may cause carcinogenicity, reproductive disorders, genotoxicity, nephrotoxicity, terratogenicity, hepatotoxicity, and immunosuppression [5, 6].
Aspergillus spp., Alternaria spp., Fusarium spp., and Penicillium spp. are the most common postharvest and storage fungi of fruits [7]. In developing countries there are unfit storage facilities, inappropriate packaging and transportation which make the post-harvest product quite difficult to handle or market. Low temperature and high humidity are required to store and transport fresh products as low temperature lowers down the microbiological, biochemical and physiological activities which help to maintain the quality [8]. A large portion of agriculture produce in the world over 
becomes unfit for consumption by man due to contamination of grains by mycotoxins produced by various fungal pathogens especially species of Aspergillus. Approximately $25 \%$ of the cereals all over the world are known to contain mycotoxins and there are almost 300 fungal metabolites that are known to be toxic to animals and human beings [9]. Approximately 400 distinct mycotoxins have been discovered. The most significant among them are aflatoxins and ochratoxin A [10]. Species of Aspergillus and Penicillium produce ochratoxin A. Ochratoxin A have numerous detrimental effects. It is neurotoxic, nephrotoxic, genotoxic, hepatotoxic, teratogenic and has immunosuppressive properties [11]. Aspergillus niger is the causal organism for black mould of garlic, onion and shallot; root stalk rot of Sansevieria; stem rot of Dracaena; and boll rot of cotton. The fungus causes spoilage of figs, vanilla, cashew kernels, dates, pods and dried prune and lives as a saprophyte in soil. Crown rot of groundnut is the most serious plant disease caused by A. niger [12]. As Aspergillus crown rot is a seed-borne disease so it drastically affects plant in the crop's life cycle and cause certain losses. They are recorded as frequent as two plants per meter of planted row [13]. A. niger also causes otomycosis, an ear infection in humans [14], pulmonary infections including pneumonia [15] and tracheobronchitis [16]. Agrichemicals are quite vital to fight against plant diseases and in maintaining high crop yields. However, excessive use of these chemicals has adverse effect on environment, including ecological imbalance of soils and making plants more susceptible to diseases and pests [17]. Increasing public awareness on environmental issues demands alternative disease management systems, which are dependent to a lesser extent on synthetic chemicals or based on naturally occurring compounds [18]. The plants are a rich source of phytochemicals that can be used as pesticides and are more ecofriendly than synthetic chemicals [19].

Approximately two-third of the world's population depends on ethnomedicines. Almost $\quad 7000 \quad$ medicative/officinal compounds that are being utilized in drug formulation are plant based. This made natural-product chemists, botanists, ethnopharmacologists and microbiologists to explore phytochemicals of medicinal importance [20]. Antifungal compounds are present in a number of plant species, which are used to restrain fungal pathogens [21]. In search for new standardized antifungals, green plants are an excellent choice, as secondary metabolites are cosmopolitan among green plants [22]. Genus Ficus (Moraceae) consists of about 40 genera and 1400 species of trees, shrubs, vines and herbs [23]. Ficus religiosa $\mathrm{L}$. is one of the most important species of the genus widely used in traditional medicines. Stem bark of this plant is known to possess several biological activities and is used for the treatment of skin diseases, nervous disorders, diabetes, anxiety, urino-genital disorders, wounds and hemorrhoids [24] [25-27]. The present study was carried out to study the antifungal activity of the stem bark extracts of the plant against $A$. niger.

\section{Materials and methods Chemicals}

All the solvents used for extraction were of analytical grade, purchased from Fischer scientific. Reagents used for phytochemical analyses, antioxidant activity and antifungal activity were purchased from Sigma Aldrich.

\section{Equipment}

In order to concentrate the extracts Rota vapor R-210 was used. UV-Visible spectra were obtained using $\mathrm{MeOH}$ with $\mathrm{UV}-\mathrm{Vis}$ spectrophotometer (UV-6000). 


\section{Collection and identification of plant material}

Stem bark material of $F$. religiosa was collected from Lahore College for Women University, Jail Road, Lahore. For identification of plants, Flora of Pakistan and other available literature was consulted.

\section{Extraction and fractionation}

The stem bark was grounded to give fine powder. The powdered material was weighed and extracted in methanol at room temperature. The solvent was filtered and recovered in rotary evaporator at $35^{\circ} \mathrm{C}$ to Table 1. Extraction yield of different solvent extracts of $F$. religiosa

\begin{tabular}{|l|c|c|c|c|c|c|}
\hline $\begin{array}{l}\text { Dry weight } \\
(\mathbf{g})\end{array}$ & $\begin{array}{l}\text { Crude methanol } \\
(\mathbf{g})\end{array}$ & $\begin{array}{l}\text { n-hexane } \\
(\mathbf{g})\end{array}$ & $\begin{array}{l}\text { Dichloro } \\
\text { methane }(\mathbf{g})\end{array}$ & $\begin{array}{l}\text { Ethyl acetate } \\
(\mathbf{g})\end{array}$ & $\begin{array}{c}\boldsymbol{n} \text {-Butanol } \\
(\mathbf{g})\end{array}$ & $\begin{array}{c}\text { Aqueous } \\
(\mathbf{g})\end{array}$ \\
\hline 120.57 & 8.4 & 1.1 & 4.56 & 0.42 & 0.8 & 0.1 \\
\hline$\%$ Yield & $7 \%$ & $13 \%$ & $55 \%$ & $5 \%$ & $9 \%$ & $1.1 \%$ \\
\hline
\end{tabular}

Phytochemical analysis

Qualitative phytochemical analysis of the extracts was carried out for the determination of preliminary phytoconstituents present in the plant extract using standard methods [28].

\section{Tests for alkaloids}

a) Dragendorff's test: For detection of alkaloids, 3-5 drops of Dragendorff's reagent (solution of potassium bismuth iodide) were added in extract solution prepared. After sometime, orange yellow precipitation were formed which confirmed the presence of alkaloids.

b) Tannic acid test: Extract of both plants was treated with tannic acid. Formation of buff color precipitates ensured the presence of alkaloids.

\section{Tests for glycosides}

For the detection of glycosides, $1 \mathrm{~mL}$ of $\mathrm{KOH}(10 \%)$ was added in $1 \mathrm{~mL}$ of extract. Appearance of brick red precipitates indicated the presence of glycosides.

Tests for flavonoids

a) Alkaline Reagent Test: To the solutions of extract prepared few drops of $10 \% \mathrm{NaOH}$ solution were added. Appearance of yellow color which disappeared on the addition of obtain crude methanol extract. The crude extract was dissolved in distilled water and subjected to liquid-liquid partitioning for initial separation of compounds based on their relative solubility in solvents of different polarities. For this purpose the crude extract suspended in distilled water was sequentially partitioned using $n$-hexane, dichloromethane, ethyl acetate and $n$ butanol. All the fractions were concentrated in rotary evaporator and were stored at a temperature of $4^{0} \mathrm{C}$ till further use. dil. acid indicated the presence of flavonoids.

b) In $3 \mathrm{~mL}$ of plant extract, $4 \mathrm{~mL}$ of $1 \%$ $\mathrm{KOH}$ was added. Appearance of dark yellow color was indicative of flavonoids.

c) Few drops of $\mathrm{AlCl}_{3}$ were added to $2 \mathrm{~mL}$ of each plant sample. The solution turned yellow indicating flavonoids.

d) A few drops of conc. $\mathrm{HCl}$ were mixed with $2 \mathrm{~mL}$ of plant extract. Appearance of red color indicated the presence of flavonoids.

\section{Tests for saponins}

For detection of saponins $2 \mathrm{~mL}$ of the extract was mixed with $2 \mathrm{~mL}$ of distilled water and vigorously shaken. Formation of stable foam confirmed the presence of saponins.

\section{Tests for xanthoproteins}

In $1 \mathrm{~mL}$ of extract solution added few drops of conc. $\mathrm{HNO}_{3}$ and $\mathrm{NH}_{3}$ solution separately. Appearance of reddish orange precipitates detected the presence of xanthoproteins.

\section{Tests for phenols}

a) Ferric Chloride Test: To $2 \mathrm{~mL}$ of plant extract, $5 \% \mathrm{FeCl}_{3}$ were added. A deep blue coloration of the solution confirmed the presence of phenols. 
b) Nitric acid test: Bark extract mixture was treated with dilute $\mathrm{HNO}_{3}$. Appearance of reddish to yellow color confirmed the presence of phenols.

\section{Tests for tannins}

a) Ferric chloride test: Addition of 3 drops of $5 \% \mathrm{FeCl}_{3}$ to I $\mathrm{mL}$ of extract led to the production of a blue or greenish-black color which changed to olive green color on progressive addition of $\mathrm{FeCl}_{3}$ indicating the presence of tannins.

b) Potassium dichromate test: $5 \mathrm{~mL}$ of the extract was mixed with $1 \mathrm{~mL}$ of potassium dichromate solution (10\%). Appearance of yellow precipitates indicated the presence of tannins.

\section{Tests for terpenoids}

a) In $1 \mathrm{~mL}$ of bark extract added 5 drops of conc. $\mathrm{H}_{2} \mathrm{SO}_{4}$. Formation of red/blue green coloration indicated the presence of terpenoids.

b) To $5 \mathrm{~mL}$ of plant sample were added 2 $\mathrm{mL}$ of $\mathrm{CHCl}_{3}$ and $3 \mathrm{~mL}$ of conc. $\mathrm{H}_{2} \mathrm{SO}_{4}$. The presence of terpenoids was confirmed by formation of an interface with reddish brown coloration.

\section{Test for sterols}

In $5 \mathrm{~mL}$ extract solution, $2 \mathrm{~mL}$ of $\mathrm{CHCl}_{3}$ was added. To the mixture formed added 3 $\mathrm{mL}$ of conc. $\mathrm{H}_{2} \mathrm{SO}_{4}$ carefully along the side of wall of test tube forming a layer.
Formation of fused reddish brown coloration indicated the presence of terpenoids.

\section{Tests for quinones}

Conc. $\mathrm{HCl}$ was added in $1 \mathrm{~mL}$ of plant extract. Formation of yellow precipitates confirmed the presence of quinones.

\section{Tests for anthraquinones}

To each plant extract was added the solution of $\mathrm{NaOH}$. Appearance of violet or pink color in base layer confirmed the presence of anthraquinones.

\section{Determination of total phenolic content}

For estimation of total phenols $20 \mu \mathrm{l}$ of each sample were mixed with $158 \mu \mathrm{l}$ of deionized water and $100 \mu \mathrm{l}$ of FC reagent and incubated for $10 \mathrm{~min}$ at room temperature. After incubation $300 \mu \mathrm{l}$ of $\mathrm{Na}_{2} \mathrm{CO}_{3}$ solution $(25 \% \mathrm{w} / \mathrm{v})$ was added to the mixture and was again incubated at $40^{\circ} \mathrm{C}$ for 30 minutes and finally cooled to room temperature. Absorbance was measured at $765 \mathrm{~nm}$ against the methanol used as blank [29]. A calibration curve of the standard gallic acid was constructed under similar conditions (Figure 1) and TPC, measured as mg gallic acid equivalent (GAE)/g dry extract (dE), was calculated using the equation: $y=0.086 x+0.0065 R^{2}=0.842$

Where $\mathrm{y}$ is the absorbance and $x$ is the concentration of gallic acid.

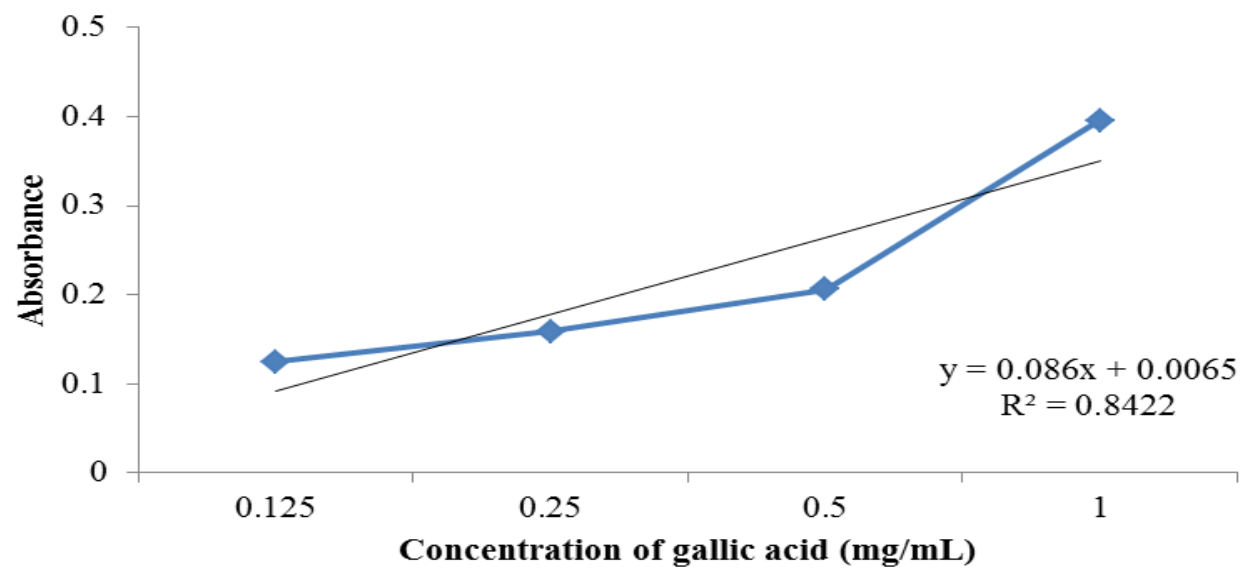

Figure 1. Calibration curve of gallic acid 
Determination of total flavonoid content Flavonoid contents in each fraction were assessed by colorimetric method using $\mathrm{AlCl}_{3}$ [30]. To $250 \mu \mathrm{l}$ of the plant sample were added $400 \mu \mathrm{l}$ de-ionized water and $90 \mu \mathrm{l}$ of $\mathrm{NaNO}_{2}$ solution $(5 \%)$ and incubated for 6 min at room temperature. $180 \mu \mathrm{l}$ of $\mathrm{AlCl}_{3}$ $(10 \%)$ was added to the above mixture and incubated again for $5 \mathrm{~min}$ at room temperature. Finally $600 \mu \mathrm{l}$ of $1 \mathrm{M} \mathrm{NaOH}$ solution was added to the mixture and diluted to $3 \mathrm{ml}$ with de-ionized water.
Absorbance was measured with a spectrophotometer at $510 \mathrm{~nm}$ using methanol as blank. For calculation of flavonoid content, calibration curve of quercetin as standard was prepared under similar conditions (Figure 2). Total flavonoid content was expressed as $\mathrm{mg}$ quercetin equivalent $(\mathrm{QE}) / \mathrm{g}$ dry weight (dw). $\mathrm{y}=0.9547 \mathrm{x}+0.4935, \mathrm{R}^{2}=0.968$

Where $\mathrm{y}=$ absorbance and $x=$ concentration of quercetin

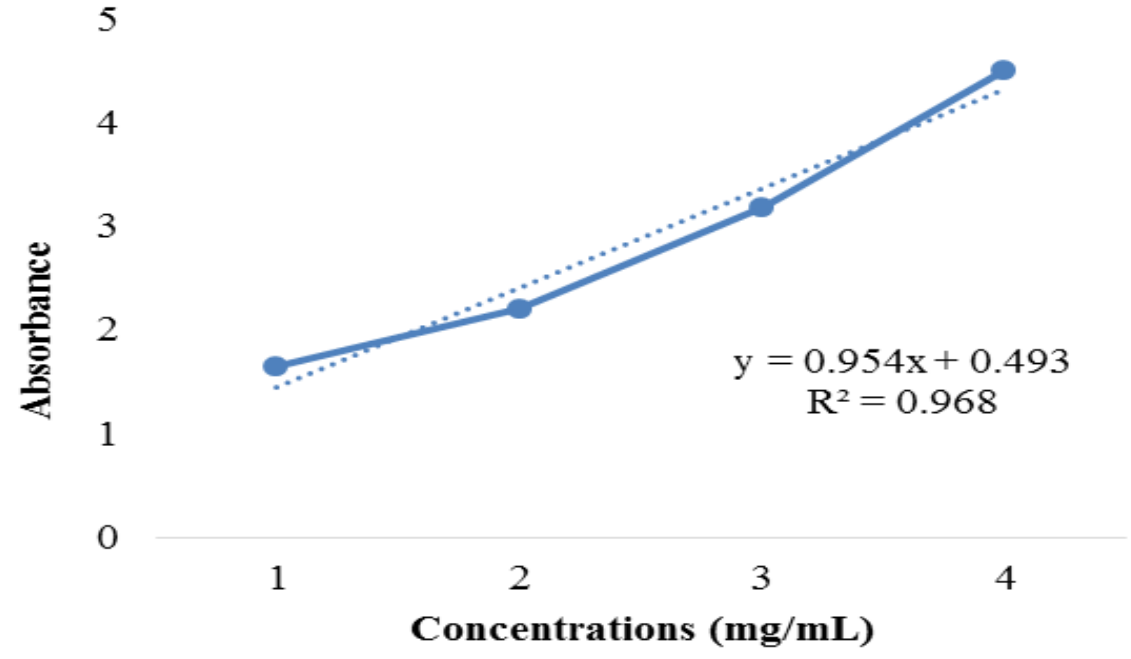

Figure 2. Calibration curve of quercetin

\section{Determination of total tannin content}

For determination of total tannins method Ram and Mehrotra was adopted [31]. To 0.1 $\mathrm{ml}$ of each plant extract, $0.5 \mathrm{ml}$ of Folin Phenol reagent and $1 \mathrm{ml}$ of $35 \%$ sodium carbonate solution was added. The final volume was made up to $10 \mathrm{ml}$ with distilled water. The mixture was vigorously shaken and left to stand at room temperature for 30 min. Absorbance was measured at $725 \mathrm{~nm}$. Blank contained water in place of plant sample. A calibration curve of gallic acid was prepared using different concentrations treated in the same manner as described above and total tannins were calculated by the following equation: $y=0.086 x+0.0065, R^{2}=0.842$

Where

$\mathrm{y}=$ absorbance

$\mathrm{x}=$ concentration of gallic acid

Results were expressed in terms of gallic acid $\mathrm{mg} / \mathrm{g}$ of extract.

\section{DPPH radical scavenging activity}

To determine the antioxidant activity $5 \mathrm{~mL}$ of $0.05 \mathrm{mM}$ of methanol extract of DPPH was mixed with $50 \mu 1$ of plant samples (at $0.125,0.25,0.50,1,2,4 \mathrm{mg} \mathrm{mL}^{-1}$ ) and incubated for 30 minutes at room temperature. Absorbance was determined at $517 \mathrm{~nm}$ using methanol as blank. The control had all the reagents except plant sample. The change in color of reaction 
mixture from violet to yellow indicated the occurrence of antioxidant activity. The \% inhibition of DPPH radical was calculated using the following formula [32].

$\%$ DPPH Scavenging activity $=\lfloor$ Absorbance of control - Absorbance of extract $\rceil$ x 100

\section{(Absorbance of control)}

Antifungal assay

Antifungal assay was performed using agar dilution method adopted by Javaid and Sammad [33].

\section{Media preparation}

Malt extract agar (MEA) medium was used for fungal growth. Medium was prepared by adding $2 \mathrm{~g}$ of malt and $2 \mathrm{~g}$ of agar in $100 \mathrm{ml}$ of distilled water in $250 \mathrm{ml}$ of conical flask and was sterilized by autoclaving at $15 \mathrm{lbs}$ inch $^{-2}$ for $15-20$ minutes at $121^{\circ} \mathrm{C}$. After autoclaving the sterilized medium was cooled to room temperature. The sterilized medium was then placed in culture room until use.

\section{Procurement and culturing of $A$. niger}

The pure culture of $A$. niger strain taken from Fungal Biotechnology Laboratory, Department of Botany, Lahore College for Women University was placed on solidified $2 \%$ MEA medium. It turned into a colony within 10 days of incubation at $20^{\circ} \mathrm{C}$.

\section{Preparation of sample solutions}

Stock solution $(30 \mathrm{mg} / \mathrm{mL})$ of each fraction was prepared by dissolving $300 \mathrm{mg}$ of each fraction in $10 \mathrm{~mL}$ of distilled water. Working concentrations of each sample at $0.25,0.5,1$ and $2 \mathrm{mg} / \mathrm{mL}$ of malt extract were prepared by using the following formula:

$\mathrm{C}_{1} \mathrm{~V}_{\mathrm{I}}=\mathrm{C}_{2} \mathrm{~V}_{2}$

Where

$\mathrm{C}_{1}=$ concentration of stock solution

$\mathrm{V}_{1}=$ volume of stock solution

$\mathrm{C}_{2}=$ working concentration of tested sample

$\mathrm{V}_{2}=$ total volume required of test sample

\section{Antifungal screening assay}

Malt extract (ME) was prepared by adding $20 \mathrm{~g} \mathrm{ME}$ in $1000 \mathrm{~mL}$ of distilled water and autoclaved at $121^{\circ} \mathrm{C}$ for 30 minutes in four conical flasks of $250 \mathrm{~mL}$ and cooled at room temperature. Teramycitin capsule at 50 $\mathrm{mg} / 100 \mathrm{~mL}$ of the medium was added to avoid bacterial contamination. Four concentrations viz. $0.25,0.5,1$ and 2 $\mathrm{mg} / 60 \mathrm{~mL}$ were prepared by adding $0.5,1,2$ and $4 \mathrm{~mL}$ of stock solution in 59.5, 59, 58 and $56 \mathrm{~mL}$ prepared broth respectively, to make the total volume of the medium up to $60 \mathrm{~mL}$. The $60 \mathrm{~mL}$ of each treatment was divided into three equal portions in $250 \mathrm{~mL}$ conical flasks to serve as replicates. Mycelial discs $(5 \mathrm{~mm})$ were prepared from 5-7 days old culture of A. niger using a presterilized cork borer and were placed in each experimental flask. The flasks were incubated for 7 days at $25^{\circ} \mathrm{C}$. After 7 days the fungal biomass from each flask was obtained by filtration of malt extract through pre-weighted Whatmann No.1 filter paper and dried up to stable weight in an electric oven and weighed. Fungal growth inhibition (\%) was calculated by applying the formula:

Growth inhibition $(\%)=\underline{\text { Growth in control }- \text { Growth in treatment }} \times 100$

Medium containing malt extract, antibiotic and fungal disc without plant extract were used as positive control while DMSO replacing plant extract served as negative control. No antifungal activity was shown by negative control.

All the experiments were performed in triplicates and results were expressed as mean \pm SE. The data was statistically analyzed by applying ANOVA followed by Duncan's Multiple Range Test at significance level of $\mathrm{P}=0.05$ using co-stat software.

\section{Results and discussion}

Phytochemical analysis

The qualitative analysis of crude methanol extract indicated the presence of glycosides, 
alkaloids, flavonoids, phenolics, phytosterols, saponins, tannins, triterpenes, terpenoids, xanthoproteins, while anthraquinones, Coumarins and quinones were absent.

\section{Quantitative phytochemical analysis}

All the fractions were analyzed to quantify the total phenolic, total flavonoid and total tannin contents. The highest content of phenolics, flavonoids and tannins was determined for the ethyl acetate fraction (0.9 $\mathrm{mg} \mathrm{GAE} / \mathrm{g} \mathrm{dE}, 0.47 \mathrm{mg} \mathrm{QE} / \mathrm{g} \mathrm{dE}$ and 2.54 $\mathrm{mg} \mathrm{GAE} / \mathrm{g} \mathrm{dE}$ respectively) while least was in dichloromethane fraction $(0.04 \mathrm{mg}$
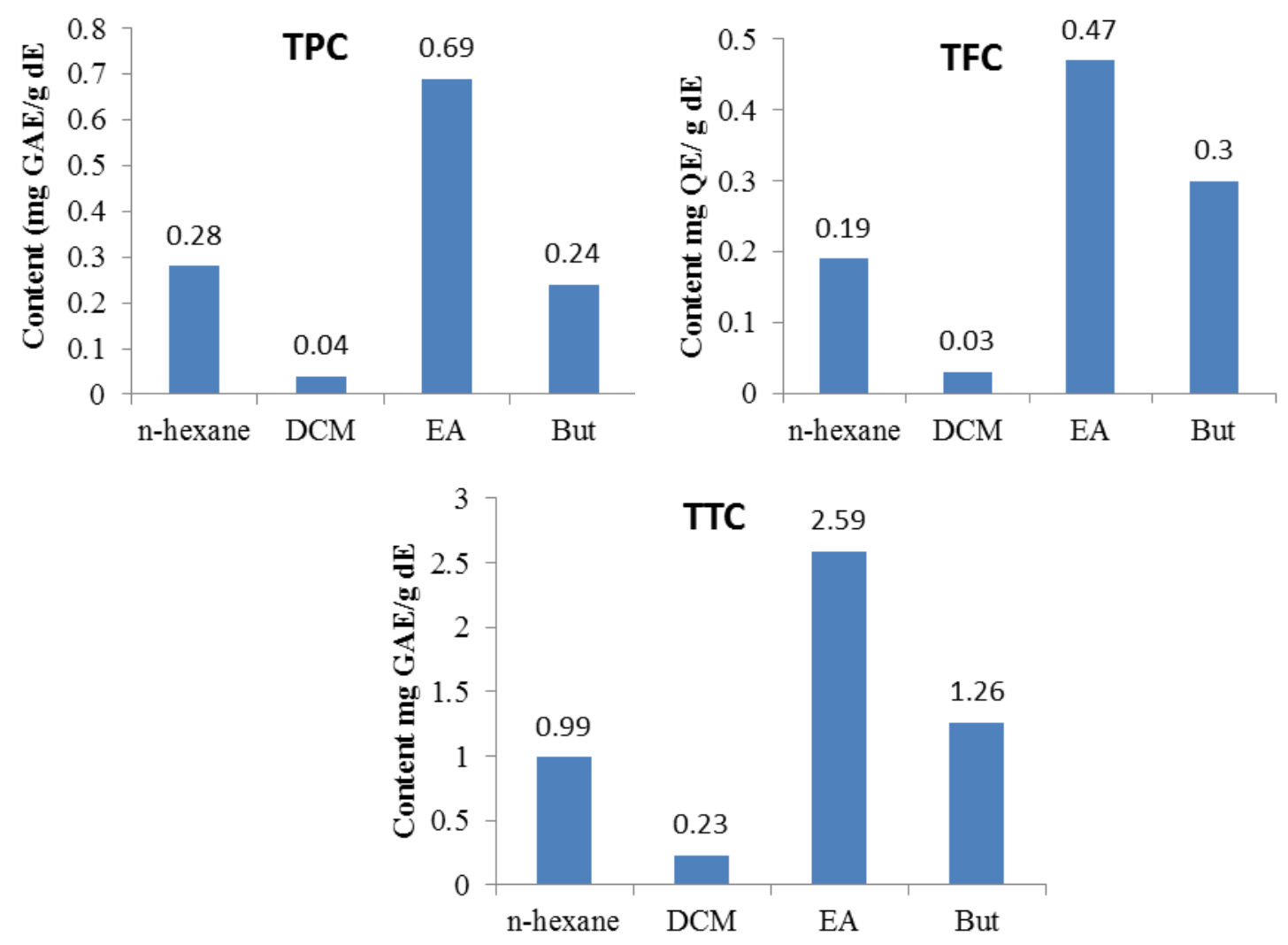

Figure 3. Total content of phenols, flavonoids and tannins in different fractions of $F$. religiosa

\section{Antioxidant assay}

The extracts showed significant antioxidant activity for all the fractions at all the tested concentrations. The inhibitory effect of the extracts ranged between 70.43-82.5\% for $n$ butanol and ethyl acetate fraction respectively at the lowest tested

GAE/g dE, $0.03 \mathrm{mg} \mathrm{QE} / \mathrm{g} \mathrm{dE}$ and $0.23 \mathrm{mg}$ $\mathrm{GAE} / \mathrm{g} \mathrm{dE}$ respectively) (Figure 3).These secondary metabolites have a major role in antifungal activity of plant extracts. Research has indicated that phenolic compounds synthesized in uninfected, healthy plant tissues, can act as antifungal compounds. These may include phenolic acids, simple phenols, flavanols and alkaloids [34]. Flavonoids are particularly strong agents against microbes, oxidative stress, allergies, cancer and inflammation [35].

TTC 2.59 
activity of stem bark range from non-polar in hexane and dichloromethane to medium polar in ethyl acetate and to highly polar in butanol fraction. This shows that the bark contains a wide range of antioxidants belonging to different classes of compounds. Antioxidant activity and quantitative analysis was correlated as ethyl acetate extract with highest phenols, flavonoids and tannin contents also had significant antioxidant activity. The results showed that all the extracts, specifically ethyl acetate extract, can be a rich source of natural antioxidants and can be used for treating

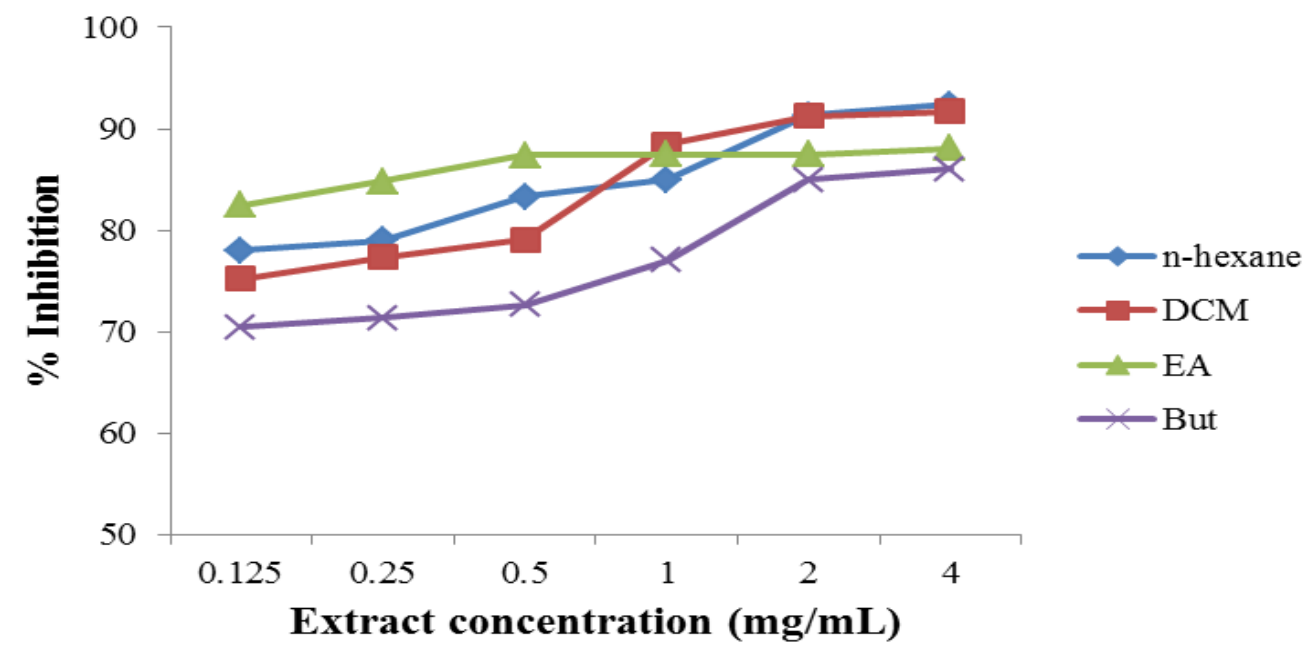

Figure 4. DPPH radical scavenging activity of $F$. religiosa stem bark extracts

\section{Antifungal assay}

In the present study different concentrations $(0.25, \quad 0.5, \quad 1,2 \mathrm{mg} / \mathrm{mL})$ of respective fractions were applied in vitro against test fungus to check their antifungal potential. The results were presented in terms of fungal biomass and percentage of growth inhibition at different extract concentrations. A decrease in fungal biomass as compared to control was observed in the presence of all the plant extracts indicating growth inhibition potential of the plant material. The inhibitory effect was dose dependent. Highest antifungal activity in terms of decrease in fungal biomass was observed in $n$-butanol extract with \% inhibition in fungal growth ranging from $66 \%$ to $77.5 \%$ at 0.125 diseases which result from oxidative stress. The phenolic, flavonoids and tannin contents in plant extract mostly act as antioxidants to prevent disease and promote the health. The observed antioxidant activity of the extracts may support the use of the plant in traditional medicines. Reports are available where the extracts of different Ficus species have shown antioxidant activity [36-38]. In all these studies the antioxidant activity was correlated to the presence of secondary metabolites including phenolics, flavonoids and anthocyanins. 
fruits of $F$. religiosa for their antifungal activity against $A$. niger in terms of zones of inhibition. All the plant parts showed antifungal activity. However, the extract was used at a very high concentration $(30,40$ and $100 \mathrm{mg} / \mathrm{mL}$ ). In the present study the crude methanol extract was fractionated into different fractions using solvents of different polarities and the resultant fractions gave significant results reducing fungal growth at very low concentrations $(0.125,0.25,0.5,1$ and $2 \mathrm{mg} / \mathrm{mL}$ ) due to partitioning of targeted compounds in different solvents according to their polarity. The observed antifungal activity may be due to the presence of secondary metabolites including phenolics, flavonoids and tannins in the bark material which have previously been reported to possess antifungal activity [42-44]. The results clearly indicated that the bark material of the tested plant can be used as a source for plant based natural antifungal compounds active against $A$. niger which is a major issue in our agriculture sector affecting a large portion of agriculture produce due to poor storage conditions.

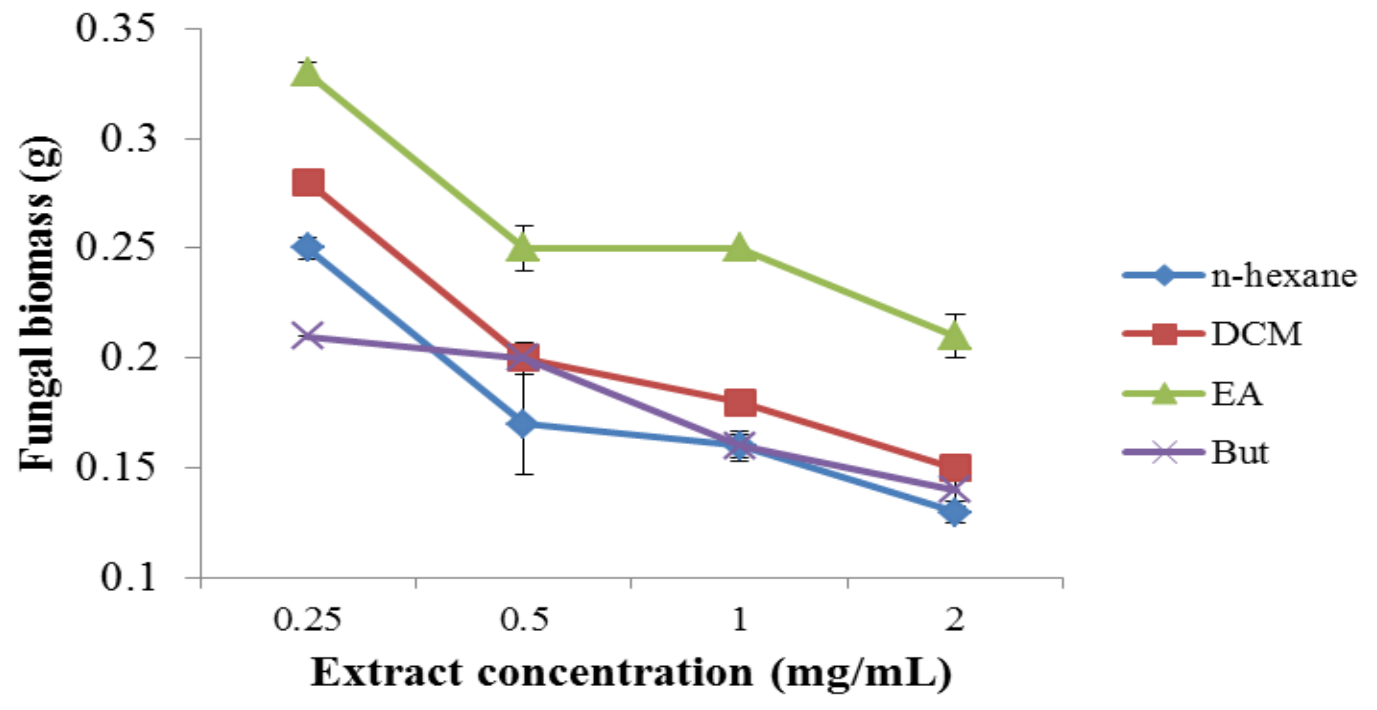

Figure 5. Decrease in fungal biomass of $A$. niger by $F$. religiosa bark extracts

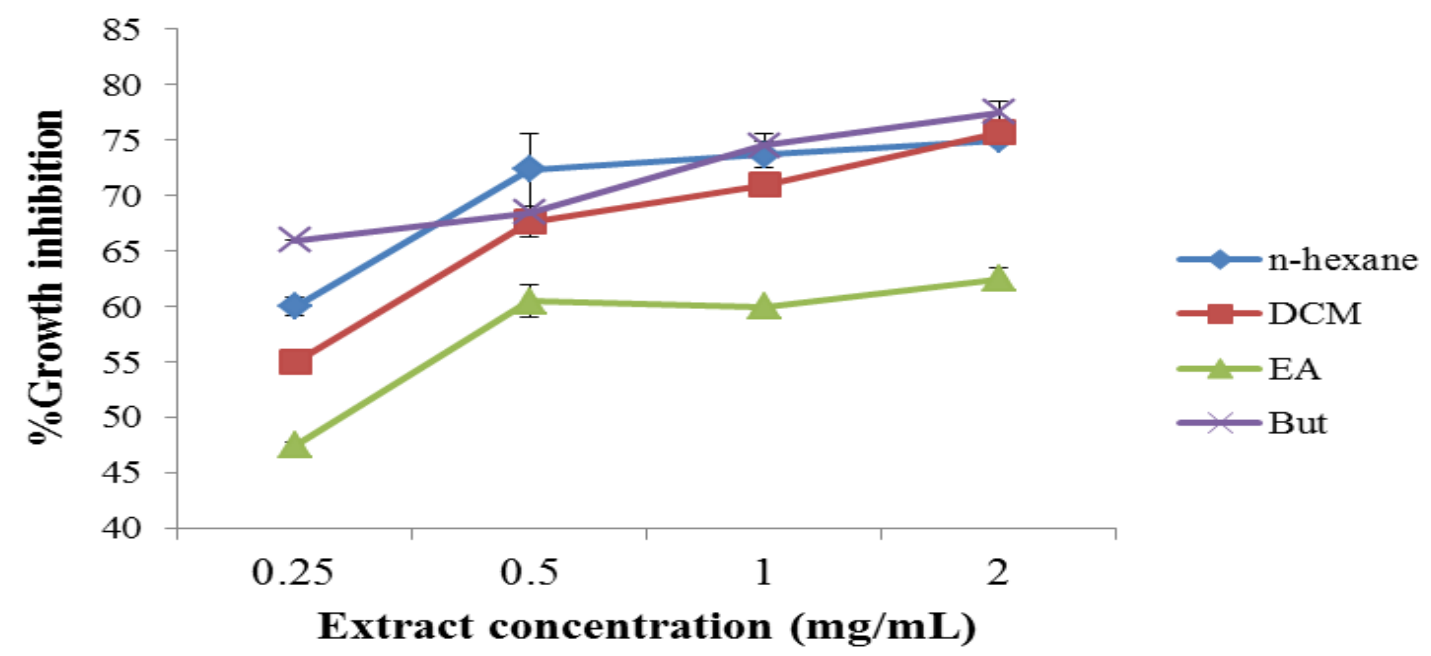

Figure 6. Inhibition of $A$. niger growth by $F$. religiosa bark extracts 


\section{Conclusion}

The results concluded that the stem bark of $F$. religiosa is rich in phytochemicals with antifungal and antioxidant activity. The $n$ butanol fraction of the bark material had highest antifungal activity indicating that the fraction had maximum amount of phytochemicals with antifungal potential. The ethyl acetate fraction can be a good source of antioxidants.

\section{Authors' contributions}

Conceived and designed the experiments: $\mathrm{Z}$ Saddiqe \& K Jabeen, Performed the experiments: A Shahid, Analyzed the data: A Shahid \& Z Saddiqe, Contributed reagents/ materials/ analysis tools: $Z$ Saddiqe \& K Jabeen, Wrote the paper: Z Saddiqe.

\section{References}

1. Owolade OF, Amusa, AN \& Osikanlu, YOK (2000). Efficacy of certain indigenous plant extracts against seed borne infection of Fusarium moniliforme on maize (Zea mays) in southwestern Nigeria. Cereal Res Commun 28: 323-327.

2. Singh RS (2002). Introduction to principles of plant pathology, Oxford and IBH Publ. Co Pvt. Ltd. New Delhi.

3. Adebanjo A (2004). Man and Plant Microbes Struggle: A Winner? An Inaugural Lecture delivered at Olabisi Onabanjo University, Ago-Iwoye. Publ. OlabisiOnabanjo Uni. Press, Ago-Iwoye, Nigeria.

4. Onyeani CA, Osunlaja SO, Oworu OO \& Joda AO (2012). Evaluation of effect of aqueous plant extract in the control of storage fungi. IJSTR 1(6): 76 - 79.

5. Zain ME (2011). Impact of mycotoxins on humans and animals. $J$ Saudi ChemSoc 15: 129-144.

6. Desjardins AE, Manandhar G, Plattner RD, Maragos CM, Shrestha K \& McCormick SP (2000). Occurrence of Fusarium species and mycotoxins in
Nepalese maize and wheat and the effect of traditional processing methods on mycotoxin levels. J Agric Food Chem 48: 1377-1383.

7. Bhale UN (2011). Survey of market storage diseases of some important fruits of Osmannabad District (M. S.) India. Sci Res Report 1: 88-91.

8. M Cecilia do Nascimento Nunes (2008). Impact of environmental conditions on fruit and vegetable quality. Stewart Postharvest Review 4: 1-14.

9. Galvano F, Piva A, Ritieni A \& Galvano G (2001). Dietary strategies to counteract the effect of mycotoxins: a review. J Food Protect 64: 120-131.

10. FAO (Food and Agriculture Organization of United Nations). 2001. Manual on the application of the HACCP system in mycotoxin prevention and control 73, FAO Food and Nutrition Paper, Rome.

11. Petzinger E \& Ziegler K (2000). Ochratoxin A from a toxicological perspective. J Vet Pharmacol Ther 23: 91-98.

12. Raji R \& Raveendran K (2013). Antifungal activity of selected plant extracts against phytopathogenic fungi Aspergillus niger. Asian Journal of Plant Science and Research 3(1):13-15.

13. Bellgard S (2004). Common diseases of peanuts in the top end of the NT. Agnote 820(62): 1-8.

14. Kumar A (2005). Fungal spectrum in otomycosis patients. $J$ K Science 7(3): 152-155.

15. Person AK, Chudgar SM, Norton BL, Tong BC \& Stout JE (2010). Aspergillus niger an unusual cause of invasive pulmonary aspergillosis. $J$ Med Microbiol 59: 834 - 838.

16. Xavier MO, Sales MPU, Camargo JJP, Pasqualotto AC \& Severo LC (2008). Aspergillus niger causing 
tracheobronchitis and invasive pulmonary aspergillosis in a lung transplant recipient: case report. Rev Soc Bras Med Trop 41: 200-201.

17. Mancini F, Termorshuizen AJ, Jiggins JLS \& Bruggen AHC (2008). Increasing the environmental and social sustainability of cotton farming through farmer education in Andhra Pradesh India Agr Syst 96: 16-25.

18. Cuthbertson AGS \& Murchie AK (2005). Economics spray thresholds in need of revision in Northern Irish Bramleyorchards. Biodiversity News 32: 19.

19. Hashim MS \& Devi KS (2003). Insecticidal action of the polyphenolic rich fraction from the stem bark of Streblusasper on Dysdercuscingulatus. Fitoterapia 74: 670-676.

20. Tanaka JCA, Da Silva CC, De Oliveira AJB, Nakamura CV \& Filho BPD (2006). Antibacterial activity of indole alkaloids from Aspidosperma ramiflorum. Braz J Med Biol Res 39(3): 387-391.

21. Bajwa R, Javaid A, Shafique S, Javaid A, Jabeen K \& Shafique S (2008). Fungistatic activity of aqueous and organic solvent extracts of three rice varieties against phytophathogenic fungi. Allelopathy Journal 22: 363-370.

22. Coleman JJ, Ghosh S, Okoli I \& Mylonakis E (2011). Antifungal activity of microbial secondary metabolites. PLoS One 6: e25321.

23. Zerega NJC, Clement WL, Datwley SL \& Weiblen GD (2005). Biogroegraphy and divergence times in the mulberry family Moraceae. Mol Phylogenet Evol 37(2): 402-416.

24. Khanom F, Kayahara H \& Tadasa K (2000). Superoxide-scavenging and prolyl endopeptidase inhibitory activities of Bangladeshi indigenous medicinal plants. Biosci Biotechnol Biochem 64:837-840.

25. Kalyon R, Shivakumar H \& Sarkar S (2009). Wound Healing Potential of Leaf Extracts of Ficus religiosa on Wistar albino strain rats. International $J$ Pharm Tech Res 1(3): 506-508.

26. Pandit R, Phadke A \& Jagtap A (2010). Antidiabetic effect of Ficus religiosa extract in streptozotocin-induced diabetic rats. J Ethnopharmacol 128: 462-466.

27. Khan MSA, Hussain SA, Jais AMM, Zakaria ZA \& Khan M (2011). Antiulcer activity of Ficus religiosa stem bark ethanolic extract in rats. JMPR 53: 354-359.

28. Harborne JB (1978). Phytochemical methods, $3^{\text {rd }}$ ed.Chapman and Hall, London. pp. 135-203.

29. Cliffe S, Fawer M, Maier G, Takata K \& Ritter G (1994). Enzyme assays for the phenolic content of natural juices. $J$ Agric Food Chem 42: 1824-1828.

30. Dewanto V, Wu X, Adom KK \& Liu RH (2002). Thermal processing enhances the nutritional value of tomatoes by increasing total antioxidant activity. J Agric Food Chem 50(10): 3010-3014.

31. Ram PR \& Mehrotra BN (1993). Compendium of Indian Medicinal Plants, (Drug Research Preparative: A CDRI Series).Central Drug Research Institute, Lucknow and Publications and Information Directorate, New Delhi. 2: 453.

32. Hatano $\mathrm{T}$, Kagawa $\mathrm{H}$, Yasuhara $\mathrm{T} \&$ Okuda T (1998). Two new flavonoids and other constituents in licorice root; their relative astringency and radical scavenging effects. Chem Pharm Bull 36: 2090-2097.

33. Javaid A \& Samad S (2012). Screening of allelopathic trees for their antifungal potential against Alternaria alternate 
strains isolated from dying back Eucalyptus spp. Nat Prod Res 26: 16971702.

34. Mohammadi M \& Kazemi H (2002). Changes in peroxidase and polyphenol activity in susceptible and resistant wheat heads inoculated with Fusarium graminearum and induced resistance. Plant Science 162: 491 -498.

35. Janicijevic J, Tosic $\mathrm{S} \&$ Mitrovic $\mathrm{T}$ (2007). Flavonoids in Plants. Phytochemistry 9(2): 153-156.

36. Yadav YC, Srivastava DN, Saini V, Singhal S, Seth AK \& Kumar S (2011). In-vitro antioxidant activity of methanolic extraction of Ficus benghalensis L. Latex. Pharmacology online 1: 140-148.

37. Ojo OA \& Akintayo CO (2014). Assessment of antioxidant activity of Ficus asperifolia Miq aqueous extract in vitro studies. The Journal of Phytopharmacology 3(1): 16-21.

38. Kambi J, Patil A, Chithra S \& Keshava R (2014). Phytochemical screening and evaluation of antibacterial, antioxidant and cytotoxic activity of Ficus racemosa Linn. Int J Pharm Pharm Sci 6(4): 1-8.

39. Hemaiswarya S, Poonkothai, M, Raja R \& Anbazhagan C (2009). Comparative study on the antimicrobial activities of three Indian medicinal plants. Egyptian Journal of Biology 11: 52-57.

40. Rajiv P \& Sivaraj R (2012). Screening for phytochemicals and antimicrobial activity of aqueous extract of Ficus religiosa Linn. Int J Pharm Pharm Sci 4(5): 207-209.

41. Ramakrishnaiah $\mathrm{G} \&$ Hariprasad $\mathrm{T}$ (2012). Screening for phytochemicals and antimicrobial activity of aqueous extract of Ficus religiosa Linn. Int J Pharm Pharm Sci 4:54-69.

42. Oh S-O, Kim JA, Jeon H-S, Park JC, Koh YJ, Hur H \& Hur JS (2008). Antifungal activity of eucalyptusderived phenolics against postharvest pathogens of Kiwifruits. Plant Pathol J 24: 322-327.

43. Hussin NM, Muse R, Ahmad S, Ramli, Mahmood M, Sulaiman MR, Shukor MYA, Rahman MFA \& Aziz KNK (2009). Antifungal activity of extracts and phenolic compounds from Barringtonia racemosa L. (Lecythidaceae). Afr J Biotechnol 8: 2835-2842.

44. Alves CT, Ferreira IC, Barros L, Silva S, Azeredo J \& Henriques M (2014). Antifungal activity of phenolic compounds identified in flowers from North Eastern Portugal against Candida species. Future Microbiol 9: 139-146. 